\title{
Research on Building "3S” Management System for Dangerous Goods Logistics
}

\author{
Chundong Zheng \& Shuaishuai Zhang \\ College of Management and Economics, Tianjin University \\ 92 Wei Jin Road, Tianjin 300072, China \\ Tel: 86-22-2789-2006_E-mail: zcd@tju.edu.cn
}

Received: April 8, $2011 \quad$ Accepted: April 14, $2011 \quad$ doi:10.5539/ijbm.v6n9p92

\begin{abstract}
In order to meet the rapid development need of dangerous goods logistics, to quickly improve the level of dangerous goods logistics management, this paper analyses the logistics characteristics of dangerous goods compared with the common goods, puts forward a new mode named " $3 \mathrm{~s}$ " management of dangerous goods logistics, that is security management, sensitivity management and specialization management, and uses it as a standard to decompose the management contents, forms a four-level indexes system of building dangerous goods logistics management system. After that, applies the grid method and fuzzy Borda number analytic method to identify the key factors of building dangerous goods logistics " $3 \mathrm{~s}$ " management system, and according to these puts forward relevant suggestions.
\end{abstract}

Keywords: Dangerous goods, Dangerous goods logistics, "3s" management, The fuzzy Borda number analytic method, Management system

\section{Introduction}

With the rapid development of China's economy, the scale of commodity circulation continues to expand, logistics industry grows rapidly. In 2009, the total logistics amounts of China were 96.65 thousand billion, increasing $7.4 \%$ over than the previous year. The value added of logistics industry was 2.31 thousand billion, increasing $7.3 \%$ over than the previous year. Meanwhile, the professional development trend of Chinese logistics industry is more obvious, the logistics demand on dangerous goods, led by special energy, industrial chemicals, etc, increases constantly. Dangerous goods logistics has become one of the most important contents of city logistics management.

Generally dangerous goods are flammable, explosive, poisonous and corrosive. They can cause injuries, damage equipments and ruin the environment. Many countries have defined the categories and the marks of dangerous goods. China's State Administration of Work Safety published The Catalog of Hazardous Chemicals to help people easily identify them and use them correctly.

Due to the features of dangerous goods, their circulation links including storage, transportation, etc, are different from common goods'. Once accident taking place during the circulation links, it will endanger people's personal and property safety, disturb social order. Therefore, the requirements and standards of dangerous goods logistics should be stricter than common goods'. We should put the process safety as the primary target, should use professional equipments and procedures. Only realizing the safety goal, can we realize other goals such as economic benefit.

Strengthening dangerous goods logistics effective management is the need of social stability, also is the need of logistics enterprises seeking long term survival and development. So building a scientific and effective dangerous goods logistics management system is an important issue to solve for the government and logistics enterprises.

\section{The dangerous goods logistics characteristics compared with the common goods}

American logistics management association defined logistics as follows in 2003: Logistics is one part of the supply chain management, is the effective planning, implement and control of forward and reverse flows and storage plans of cargos, services and relevant information, to satisfy customer's requirements. Dangerous goods logistics is different from common goods logistics in some extents. There exit three kinds of obvious differences in logistics objects, the degrees of risk and process between them: 


\subsection{The specificity of logistics objects}

Compared with the common goods logistics, dangerous goods logistics objects have especial physical and chemical property, they're easy to cause blasting accidents, and the consequences of those will endanger people's health, damage business and social interests, and also pollute the environment.

In addition, dangerous goods have many different kinds, and each of them is different from others. According to Dangerous Goods Classification and Commodity Numbers (GB6944-2005), the current classification in China, dangerous goods are divided into 9 categories, including exploder, inflammable liquid, etc. The Name List of Dangerous Foods (GB12268-2005) sorted out 3468 kinds of dangerous goods according to the above classification. Each kind of them with special physical and chemical properties has different degrees of risk. That brings great inconvenience to logistics management.

\subsection{The specificity of risk}

The specificity of logistics objects decides the high risk of dangerous goods logistics. That is the main source of risk, and is inevitable. According to the risk assessment model of dangerous goods transportation: the transportation risk $=$ the probability of an accident $\times$ the extent of the damage caused by the accident, the large probability of logistics accident and the serious consequences decide the transportation's high risk together. Moreover, the risk of dangerous goods logistics exists in every link of supply chain, such as packing, transportation, storage and distribution. The risks are also different due to the differences in risk source's amount and type.

\subsection{The specificity of process}

As the specificity of logistics object and the risk, dangerous goods logistics need more professionalism and technicality to ensure realizing logistics process's smoothly. The professionalism and technicality are embodied in three sides: operator, equipment and operation procedure.

The operator of dangerous goods logistics should have a certain level of industrial knowledge and skill. After mastering the correct operating procedures, they should understand the nature of dangerous goods and safety precautions in order to standardize the procedure.

As for logistics equipment, the especial physical and chemical properties of dangerous goods put forward higher requirements to avoid leakage, pollution, moist, light, extrusion, shock, crash and friction, realize the special protection of dangerous goods.

The risk of dangerous goods logistics exits in the whole process, and is dynamic. So we should take professional process to analysis and choose the storage locations and transportation routes. Taking risk control measures to ensure the accident rate and consequences to a minimum.

\section{The " $3 \mathrm{~s}$ " management mode of dangerous goods logistics}

Modern logistics greatly promoted the development of national economy, covering almost the first, second and tertiary industries in all areas, and has become one of the pillar industries in the national economy.

The efficient management by optimizing and coordination logistics activities can reduce logistics cost, improve efficiency and economic benefit, better meet the customers' demand.

Due to the specificity of dangerous goods logistics, the management of dangerous goods logistics is also different from the common goods logistics. It has extra management requirements during pursuing general logistics management goals. This paper puts forward a new mode named " $3 \mathrm{~s}$ " management of dangerous goods logistics, that is security management, sensitivity management and specialization management.

\subsection{Security management}

The risk of dangerous goods logistics is much higher than general logistics. The accidents of dangerous goods can make more influence and hazards. This puts forward new requirements to logistics management. Dangerous goods logistics should pay more attention to the safety management, and put the safety management as the primary goal. Only realizing the safety of the process, can we ensure the economic benefit and other goals.

\subsection{Sensitivity management}

The possibility of a dangerous goods logistics accident exists in any part of the logistics system. Therefore, the management of dangerous goods logistics should be sensitive and keep track of logistics process and situation. Once an accident happens, we can quickly get the information and respond to it at the first time and rapidly control the situation to minimize the damage.

\subsection{Specialization management}

The realization of dangerous goods logistics is more difficult than general logistics. So the management of dangerous goods requires more professional. It should adopt advanced technology to realize and monitoring the logistics process. Only equipped with professional operators, equipments, adopting professional procedures, can effectively reduce the probability of accidents and improve the safety. 


\section{The building of dangerous goods logistics " 3 s" management system}

The safety situation of Chinese dangerous goods logistics is not optimistic. According to incomplete statistics, from August 2005 to July 2008, the number of all kinds of dangerous goods accidents happened in China was 1565 , causing 945 deaths, 8765 wounded. Among them, the dangerous goods logistics was the largest part of the accidents, accounting for $61.1 \%$ of the total number. The reasons such as the dangerous goods monitoring system of China is not perfect, the operators lack professional knowledge and safety awareness, and so on, make the logistics accidents occur frequently, bringing great damage to people's personal and property safety.

To realize " $3 \mathrm{~s}$ " management mode requirement, we need to construct a dangerous goods logistics management system with " $3 \mathrm{~s}$ " management standards. At the same time, to improve Chinese dangerous goods logistics current situation as soon as possible, build the management system in a fast and efficient manner, we need to identify the key factors of management system.

\subsection{The design of dangerous goods logistics " $3 \mathrm{~s}$ " management system}

The construction of dangerous goods logistics" $3 \mathrm{~s}$ " management system is under the influence of various factors. This paper, after careful analysis and selection, in the comprehensive and scientific basis, forms a four-level indexes system of building dangerous goods logistics management system. We put the evaluation of the building Chinese dangerous goods logistics " $3 \mathrm{~s}$ " management system as the first-class index, and set up 3 second-class indexes under the firs-class index, those are the motivation factors, capacity factors and guarantee factors. Through further decomposition and analysis, find out the third-class indexes and the fourth-class indexes which impact the second-class indexes, thereby form Table 1, the indexes system of the evaluation of building dangerous goods logistics " $3 \mathrm{~s}$ " management system.

\section{$<$ Insert Table 1 here $>$}

\subsection{Identifying the key factors of building dangerous goods logistics " $3 \mathrm{~s}$ " management system}

The building of dangerous goods logistics " $3 \mathrm{~s}$ " management system involves many fields and departments. But the identification of the key factors would point out the most critical and fast manner for it. This paper through experts scoring applies the grid method and fuzzy Borda number analytic method, identifies the key factors of building dangerous goods logistics " $3 \mathrm{~s}$ " management system on the basis of group opinions.

According to the grid method and fuzzy Borda number analytic method, this paper forms a hierarchical structure showed in Table 1, then distributes questionnaires to 10 logistics experts, letting them evaluate each index and give out the score according to the index's importance under different management requires. The scores from 1 to 5 represent different importance, being not important, general important, important, the more important and the most important. Through the analysis of the 10 questionnaires, calculate the average scores of each index to get the complete grid.

4.2.1 Determining the weights of the second-class indexes

Through calculating the average scores of the second-class indexes, get the grid of the second-class indexes.

\section{$<$ Insert Table 2 here $>$}

Analysis the grid and get the relative weights of single criterion.

We have these notations:

D: the class of index, $\mathrm{d}=1,2,3,4$.

P: the index's order under the same class, $\mathrm{p}=1, \ldots, \mathrm{P}$.

M: the attribute's order, $\mathrm{m}=1,2,3$.

Dp: the $p$ index of d-class.

Bm(Dp): the $m$ attribute's score of index Dp.

Ump : the membership of Dp for $m$ attribute, $0 \leq \mathrm{Ump} \leq 1$.

FB(DP): the fuzzy Borda number of Dp.

The analysis steps are as follows:

(1) Determine the degree

\section{$<$ Insert Table 3 here $>$}

In the evaluation of the $m$ attribute, calculate each index Dp's membership, the calculation formula is: Ump= $\mathrm{Bm}(\mathrm{Dp}) / \max \{\mathrm{Bm}(\mathrm{Dp})\},(0 \leq \mathrm{Ump} \leq 1)$.

(2) According to the following formula to calculate the fuzzy frequency tables

fhp: the fuzzy frequency of index DP.

$$
f_{h p}=\sum_{m-1}^{M} \delta_{m}^{h}\left(D_{p}\right) \times U_{m p}, \quad R_{p}=\sum_{h} f_{h p}
$$

$\mathrm{Rp}$ : the sum of fuzzy frequency of index DP. 
$\delta_{m}^{h}\left(D_{p}\right)$ : precedence relation's sparse. If $\mathrm{D}_{\mathrm{p}}$ 's order is h under m attribute, $\delta_{m}^{h}\left(D_{p}\right)$ is 1 . If not, $\delta_{m}^{h}\left(D_{p}\right)$ is 0 . $<$ Insert Table 4 here $>$

(3) Calculate fuzzy Borda number

If $\mathrm{D}_{\mathrm{p}}$ is the $\mathrm{h}$ in the precedence relation, its weight is $\mathrm{Q}_{\mathrm{h}} \cdot \mathrm{Q}_{\mathrm{h}}=\frac{1}{2} \times(\mathrm{N}-\mathrm{h})(\mathrm{N}-\mathrm{h}+1)$.

$$
F B\left(D_{p}\right)=\sum_{h} \frac{f_{h p}}{R_{p}} \times Q_{h}=\sum_{h} W_{h p} \times Q_{h}, \quad W_{h p}=\frac{f_{h p}}{R_{p}}
$$

After calculating, get the fuzzy Borda numbers of second-class indexes: $\mathrm{FB}\left(\mathrm{B}_{1}\right)=0.7097, \mathrm{FB}\left(\mathrm{B}_{2}\right)=2.6575$, $\mathrm{FB}\left(\mathrm{B}_{3}\right)=0.7937$;

(4) Normalized the fuzzy Borda number, get the weight of a single criterion

$$
W_{p}=F B\left(D_{p}\right) \div \sum_{P-1}^{N} F B\left(D_{p}\right)
$$

After calculating, get the weights of second-class indexes: $\mathrm{WB}_{1}=0.1706, \mathrm{WB}_{2}=0.6387, \mathrm{WB}_{3}=0.1907$.

4.2.2 Determining the weights of the third-class and fourth-class indexes

The determining of third-class indexes still applies the grid method and fuzzy Borda number analytic method. The steps are as follows:

(1) The process of calculating motivation factors' third-class indexes weights are showed in Table 5 to Table 7

$$
\begin{aligned}
& <\text { Insert Table } 5 \text { here> } \\
& <\text { Insert Table } 6 \text { here> } \\
& <\text { Insert Table } 7 \text { here> }
\end{aligned}
$$

After calculating, get the fuzzy Borda numbers and the weights of motivation factors' third-class indexes: $\mathrm{FB}\left(\mathrm{C}_{11}\right)=0.8583, \mathrm{FB}\left(\mathrm{C}_{12}\right)=1.3596, \mathrm{FB}\left(\mathrm{C}_{13}\right)=2.1493 ; \mathrm{WC}_{11}=0.1965, \mathrm{WC}_{12}=0.3113, \mathrm{WC}_{13}=0.4922$

(2) The process of calculating capacity factors' third-class indexes weights are showed in Table 8 to Table 10

$$
\begin{aligned}
& <\text { Insert Table } 8 \text { here> } \\
& \text { <Insert Table } 9 \text { here> } \\
& \text { <Insert Table } 10 \text { here> }
\end{aligned}
$$

After calculating, get the fuzzy Borda numbers and the weights of capacity factors' third-class indexes: $\mathrm{FB}\left(\mathrm{C}_{21}\right)=0.1842, \mathrm{FB}\left(\mathrm{C}_{22}\right)=3.3309, \mathrm{FB}\left(\mathrm{C}_{23}\right)=2.2319, \mathrm{FB}\left(\mathrm{C}_{24}\right)=2.3636 ; \mathrm{WC}_{21}=0.0227, \mathrm{WC}_{22}=0.4107$, $\mathrm{WC}_{23}=0.2752, \mathrm{WC}_{24}=0.2914$.

(3) The process of calculating guarantee factors' third-class indexes weights are showed in Table 11 to Table 13

$$
\begin{aligned}
& \text { <Insert Table } 11 \text { here> } \\
& \text { <Insert Table } 12 \text { here> } \\
& \text { <Insert Table } 13 \text { here> }
\end{aligned}
$$

After calculating, get the fuzzy Borda numbers and the weights of guarantee factors' third-class indexes: $\mathrm{FB}\left(\mathrm{C}_{31}\right)=2.0455, \mathrm{FB}\left(\mathrm{C}_{32}\right)=0.4286, \mathrm{FB}\left(\mathrm{C}_{33}\right)=1.8065 ; \mathrm{WC}_{31}=0.4779, \mathrm{WC}_{32}=0.1001, \mathrm{WC}_{33}=0.4220$.

$W_{i j}=W_{i} \times W_{i j}^{\prime},\left(\mathrm{i}=1,2,3 ; \mathrm{j}=1,2,3,4 . \mathrm{W}_{\mathrm{ij}}\right.$ is the combination weights of third-class indexes, $\mathrm{W}_{\mathrm{i}}$ is the weights of second-class indexes, $W_{i j}^{\prime}$ is the relative weights of third-class).

After calculating, get the combination weights of third-class indexes, the result showed in Table 14

$<$ Insert Table 14 here $>$

Using the scores of the weights of fourth-class indexes from experts, calculate the combination weights of fourth-class indexes.

Finally, collect all the indexes' weights and form Table 14.

\subsection{The analysis of the result of identification the key factors}

Basis on the scores given by the 10 logistics experts, we conduct further calculation and get the weights of each index for building dangerous goods logistics " $3 \mathrm{~s}$ " management system of China.

For the second-class indexes, the weights of capacity factors are the highest, far more than motivation factors and guarantee factors. This suggests that the experts generally consider the capacity factors are the most important, the most direct factors for building dangerous goods logistics " $3 \mathrm{~s}$ " management system of China. Guarantee factors' weights are the second. Its existence and improvement ensure the normal operation of the 
safety management system. Motivation factors' weights are the third. It is precipitating factors for promoting the building of dangerous goods logistics " $3 \mathrm{~s}$ " management system, and also one of the essential factors.

For the third-class indexes, technical capacity, equipment capacity and fiscal capacity are at the top three. That explains the three indexes are the key factors for promoting dangerous goods logistics management system ofChina, and reflects the importance of the direct capacity indexes. Organizational guarantee, enterprise motivation and institutional guarantee rank 4 to 6 . That explains that the three indexes are necessary parts of building and operating management system besides the direct capacity indexes. These indexes are more important than other third-class indexes.

For the fourth-class indexes, technical level, R\&D capacity and the intensity of financial investment are at the top three. Those are the most concrete selection for building " $3 \mathrm{~s}$ " management system as soon as possible. The advanced level of equipment, the scale of professional equipment, the ability of using funds, the construction of industry standards, the construction of professional logistics enterprises, the construction of safety management departments and enterprises' economic power rank 4 to 10.

\section{The suggestions about strengthening the building of dangerous goods logistics " $3 \mathrm{~s}$ " management system of China}

According to the above identification results, put forward three suggestions.

\subsection{Applying ICT to improve the existing technology level}

To ensure security, sensitivity and specialization management, we can take Information Communication Technology (ICT) to realize real-time monitoring and the whole scheduling, fully understand the operating conditions of dangerous goods transport vehicles and shorten the response time to transport accidents. Specifically, in a certain area or across the country, combine internet technology with global positioning system, geographic information system, radio frequency identification technology, establish a public monitoring platform on the internet. With wide coverage of global mobile communication network, make the contact, among in-road dangerous goods transport vehicles, logistics monitoring center and the owners of the cargo, to be possible. The application of these technologies provides an effective means to track, monitor and manage the logistics processes, makes the comprehensive supervision is no longer a problem.

In the development and the use of the technical system, should introduce multi-system developers, bring together social R\&D capabilities. The application and development of ICT technology need the support of many departments and fields. The competent industrial department can adopt R\&D cooperation or project outsourcing, and integrate universities, institutes, telecommunication operators and other social $R \& D$ capabilities to complete the ICT system development in dangerous goods logistics field, and realize a nationwide application in collaboration with regions and related departments.

\subsection{Increasing financial investments and establishing large-scale third-party dangerous goods logistics enterprises}

At present, the dangerous goods logistics enterprises of China are in small scale and scattered, they can't meet the increasing demand for transport of dangerous goods. According to the statistics by the EV123 website, Beijing now has 83 dangerous goods transport companies, but only 19 companies' scales are more than 100 people. During the 68 companies of Tianjin, only 7 companies' scales are more than 100 people. So, the dangerous goods enterprises should increase financial investments, improve the transport professional qualification, enlarge the third-party logistics enterprises' scales, purchase advanced transport equipments and strive to improve enterprise's own scale and professional level. At the same time, government can increase investment to this industry, help and encourage the building of unified national dangerous goods logistics industry's information and communication management system.

5.3 Strictly implement dangerous goods transport general specification, improve dangerous goods transport equipments level

In order to improve dangerous goods logistics' situation, the state administration of work safety published Dangerous Chemicals Auto Transportation Safety Monitoring System General Specification (AQ3003) and Dangerous Chemicals Auto Transportation Safety Monitoring Car Terminal (AQ3004) on September 1, 2005. For the effective implement of the two safety standards, the national production safety Beijing monitoring equipments' testing and inspection center of dangerous goods transport was funded on 31 December, 2005. It began to be responsible for the implementation of AQ3003 and AQ3004. However, according to the statistics by the state administration of work safety website, until March 2007, only 10 production enterprises passed product type testing of AQ3004-2005, and only 3 enterprises passed management platform's software test of AQ3003-2005, and got the test reports.

To improve the transportation equipments' level and build the effective management system, we should increase efforts to implement the above standards. Specifically, we can add transportation equipments' testing and inspection centers in different areas, and set special logistics management standards to different types of dangerous goods. 


\section{Limitations}

There are some limitations to this study. Firstly, in the process of identifying the key factors of building dangerous goods logistics " $3 \mathrm{~s}$ " management system, this paper only adopted 10 logistics experts' views, and according their scores calculated each index's weight. Future studies can expand the sample size and combine more experts' views to make the scores of each index more scientific and persuasive. Beyond that, future researchers can apply other group decision-making methods to enhance and confirm the results. Finally, there may be exist other factors which also would influence the building of dangerous goods logistics "3s" management system, so more influencing factors should be considered in the future study.

\section{Conclusion}

The rapid growth of dangerous goods logistics industry needs and the laggard management level has formed a strong disharmony. The main purpose of this study is to find out an effective method for dangerous goods logistics management, which must be different from common goods logistics. The results show that due to the particularities of dangerous goods logistics in logistics objects, the degree of risk and process, the management should put the "3s" management mode as the main principle, not only to maximize the benefits. Both the industry construction departments and the operations departments should follow the principle. In addition, this study also forms a four-level indexes system of dangerous goods logistics. Through it, we try to decompose the management contents and find out the most effective method to realize " $3 \mathrm{~s}$ " management mode. Then we take Chinese dangerous goods logistics as an example to carry out the research. The results show that the capacity factors are the main factors to effect industry construction for now. Specifically, the technical capacity plays an important role in promoting industry development. So related departments should focus on the technology research and development, through information communication technology improve management efficiency. Meanwhile, the fiscal capacity also has a high proportion among capacity factors, indicating that industry construction couldn't without financial support.

Finally, although with the development of dangerous goods logistics industry, its management level will be gradually improved, the " $3 \mathrm{~s}$ " management requirements shouldn't be changed at any stage. At different stages the key points of industry construction are different. And in different regions or countries, the key points also shouldn't be the same due to the different situations of them.

\section{References}

B. Fabiano, F. Curr, E. Palazzi \& R. Pastorino. (2002). A framework for risk assessment and decision-making strategies in dangerous good transportation. Journal of hazardous materials, (93), 1-15. doi:10.1016/S0304-3894(02)00034-1, http://dx.doi.org/10.1016/S0304-3894(02)00034-1

Bing Sun \& Bo-Zhou Li. (2003). On the dynamic research to enterprise technological innovation. Harbin Engineering University.

Eiichi Taniguchi, Russell G. Thompson \& Tadashi Yamada. (2010). Incorporating risks in city logistic s. Procedia social and behavioral sciences, (2), 5899-5910.

Hai-Yan Wang. (2009). Dangerous goods logistics safety management and emergency management research. Journal of Southeast University, 11(1), 71-74.

Hong-Jun Cao, \& Gong-Jian Kan. (2009). Logistics. Beijing: Economic Science Press.

Huang He. (2009). Accident prevention of dangerous goods logistics and emergency management research. Jiangsu Commercial Forum, (9), 64-66.

Ji-Mei Yang \& Ben-Shan Shi. (1992). Joining methods in group appraising. Systems Engineering-theory \& Practice, (1), 49-51.

Jun-Lai Zhao \& $\mathrm{Ke} \mathrm{Xu}$, (2009). Statistic analysis and countermeasures on dangerous chemical accidents in China. China Safety Science Journal, 19(7), 165-170.

Li Sun. (2006). Petrochemical dangerous goods logistics improvement based on GPS, GIS and RFID. Journal of Shanghai Maritime University, 27(Suppl.), 164-168.

Qing-Xian Zhao. (2005). The safety administration of hazardous chemicals. Beijing: China Petrochemical Press. Wei Xiao. (2006). China dangerous goods logistics management's analysis and discussion. Market Modernization, (19), 132.

Wu-Zhou Jiang. (2007). Design and realization of data transfer with WebService in RFID system. Computer Engineering and Design, 28(13), 3126-3129. 
Table 1. The indexes system of building dangerous goods logistics " $3 \mathrm{~s}$ " management system

\begin{tabular}{|c|c|c|c|}
\hline $\begin{array}{c}\text { The } \\
\text { first-class } \\
\text { index }\end{array}$ & $\begin{array}{c}\text { The } \\
\text { second-class } \\
\text { indexes }\end{array}$ & $\begin{array}{l}\text { The third-class } \\
\text { indexes }\end{array}$ & The fourth-class indexes \\
\hline \multirow{22}{*}{$\begin{array}{c}\text { The } \\
\text { building } \\
\text { of } \\
\text { Chinese } \\
\text { dangerous } \\
\text { goods } \\
\text { logistics } \\
\text { "3s" } \\
\text { management } \\
\text { system } \\
\text { A }\end{array}$} & \multirow{8}{*}{$\begin{array}{l}\text { Motivation } \\
\text { factors } \\
\mathrm{B}_{1}\end{array}$} & \multirow{3}{*}{$\begin{array}{l}\text { Social motivation } \\
\qquad \mathrm{C}_{11}\end{array}$} & Economic motivation $\mathrm{D}_{111}$ \\
\hline & & & The motivation of people's insurance $\mathrm{D}_{112}$ \\
\hline & & & The motivation of environment protection $\mathrm{D}_{113}$ \\
\hline & & \multirow{2}{*}{$\begin{array}{c}\text { Government } \\
\text { motivation } \mathrm{C}_{12}\end{array}$} & The motivation of functions $D_{121}$ \\
\hline & & & The motivation of maintaining social stability $\mathrm{D}_{122}$ \\
\hline & & \multirow{3}{*}{$\begin{array}{c}\text { Enterprise } \\
\text { motivation } \\
\mathrm{C}_{13}\end{array}$} & The motivation of enterprises' economic $\mathrm{D}_{131}$ \\
\hline & & & The motivation of social responsibility $\mathrm{D}_{132}$ \\
\hline & & & The motivation of sustainable development $\mathrm{D}_{133}$ \\
\hline & \multirow{8}{*}{$\begin{array}{l}\text { Capacity factors } \\
\mathrm{B}_{2}\end{array}$} & \multirow{2}{*}{$\begin{array}{c}\text { Personal capacity } \\
\mathrm{C}_{21} \\
\end{array}$} & The professionalism of operators $\mathrm{D}_{211}$ \\
\hline & & & The scale of operators $\mathrm{D}_{212}$ \\
\hline & & \multirow{2}{*}{$\begin{array}{l}\text { Technical } \\
\text { capacity } \mathrm{C}_{22}\end{array}$} & Technical level $\mathrm{D}_{221}$ \\
\hline & & & $\mathrm{R} \& \mathrm{D}$ capacity $\mathrm{D}_{222}$ \\
\hline & & \multirow{2}{*}{$\begin{array}{l}\text { Equipments' } \\
\text { capacity } C_{23}\end{array}$} & The advanced level of equipments $D_{231}$ \\
\hline & & & The scale of professional equipments $\mathrm{D}_{232}$ \\
\hline & & \multirow{2}{*}{$\begin{array}{l}\text { Fiscal capacity } \\
\mathrm{C}_{24} \\
\end{array}$} & The ability of using funds $\mathrm{D}_{241}$ \\
\hline & & & The intensity of financial investment $\mathrm{D}_{242}$ \\
\hline & \multirow{6}{*}{$\begin{array}{c}\text { Guarantee } \\
\text { factors } \\
\mathrm{B}_{3}\end{array}$} & \multirow{2}{*}{$\begin{array}{c}\text { Organizational } \\
\text { guarantee } \\
\mathrm{C}_{31}\end{array}$} & $\begin{array}{l}\text { The construction of safety management departments } \\
\qquad D_{311}\end{array}$ \\
\hline & & & $\begin{array}{l}\text { The construction of professional logistics enterprises } \\
\qquad D_{312}\end{array}$ \\
\hline & & \multirow{2}{*}{$\begin{array}{l}\text { Supervision } \\
\text { mechanism's } \\
\text { guaranteeC }_{32}\end{array}$} & The construction of supervision mechanism $\mathrm{D}_{321}$ \\
\hline & & & The implementation of supervision mechanism $\mathrm{D}_{322}$ \\
\hline & & \multirow{2}{*}{$\begin{array}{l}\text { Institutional } \\
\text { guarantee } \mathrm{C}_{33}\end{array}$} & Industry management rules $\mathrm{D}_{331}$ \\
\hline & & & The construction of industry standards $\mathrm{D}_{332}$ \\
\hline
\end{tabular}

Table 2. The composite scores of second-class indexes

\begin{tabular}{|c|c|c|c|}
\hline $\mathrm{B}_{\mathrm{m}}\left(\mathrm{D}_{\mathrm{P}}\right)$ & Motivation factors $\left(\mathrm{B}_{1}\right)$ & Capacity factors $\left(\mathrm{B}_{2}\right)$ & Guarantee factors $\left(\mathrm{B}_{3}\right)$ \\
\hline $\begin{array}{c}\text { Security Management } \\
\left(\mathrm{P}_{1}\right)\end{array}$ & 3.6 & 5 & 5 \\
$\begin{array}{c}\text { Sensitivity Management } \\
\left(\mathrm{P}_{2}\right)\end{array}$ & 4.2 & 4.8 & 3.6 \\
$\begin{array}{c}\text { Specialization Management } \\
\left(\mathrm{P}_{3}\right)\end{array}$ & 4.6 & 4.8 & 4 \\
\hline
\end{tabular}

Table 3. The degree of second-class indexes

\begin{tabular}{|c|c|c|c|}
\hline $\mathrm{U}_{\mathrm{mp}}$ & $\mathrm{B}_{1}$ & $\mathrm{~B}_{2}$ & $\mathrm{~B}_{3}$ \\
\hline $\mathrm{P}_{1}$ & 0.72 & 1.00 & 1.00 \\
$\mathrm{P}_{2}$ & 0.84 & 0.96 & 0.72 \\
$\mathrm{P}_{3}$ & 0.92 & 0.96 & 0.8 \\
\hline
\end{tabular}

Table 4. The statistics of fuzzy frequency of second-class indexes

\begin{tabular}{|c|c|c|c|}
\hline $\mathrm{f}_{\mathrm{hp}}$ & $\mathrm{B}_{1}$ & $\mathrm{~B}_{2}$ & $\mathrm{~B}_{3}$ \\
\hline 1 & 0 & 2.42 & 0.5 \\
2 & 1.76 & 0.5 & 0.5 \\
3 & 0.72 & 0 & 1.52 \\
\hline $\mathrm{R}_{\mathrm{p}}$ & 2.48 & 2.92 & 2.52 \\
\hline
\end{tabular}


Table 5. The composite scores of motivation factors' third-class indexes

\begin{tabular}{|c|c|c|c|}
\hline $\mathrm{B}_{\mathrm{m}}$ & $\begin{array}{c}\text { Social motivation } \\
\left(\mathrm{C}_{11}\right)\end{array}$ & $\begin{array}{c}\text { Government motivation } \\
\left(\mathrm{C}_{12}\right)\end{array}$ & $\begin{array}{c}\text { Enterprise motivation } \\
\left(\mathrm{C}_{13}\right)\end{array}$ \\
\hline $\begin{array}{c}\text { Security Management } \\
\left(\mathrm{P}_{1}\right)\end{array}$ & 4 & 4.6 & 3.8 \\
$\begin{array}{c}\text { Sensitivity Management } \\
\left(\mathrm{P}_{2}\right)\end{array}$ & 4.6 & 3.4 & 5 \\
$\begin{array}{c}\text { Specialization } \\
\text { Management } \\
\left(\mathrm{P}_{3}\right)\end{array}$ & 3.4 & 3.4 & 4.6 \\
\hline
\end{tabular}

Table 6. The degree of motivation factors' third-class indexes

\begin{tabular}{|c|c|c|c|}
\hline $\mathrm{U}_{\mathrm{mp}}$ & $\mathrm{C}_{11}$ & $\mathrm{C}_{12}$ & $\mathrm{C}_{13}$ \\
\hline $\mathrm{P}_{1}$ & 0.8 & 0.92 & 0.76 \\
$\mathrm{P}_{2}$ & 0.92 & 0.68 & 1 \\
$\mathrm{P}_{3}$ & 0.68 & 0.68 & 0.92 \\
\hline
\end{tabular}

Table 7. The statistics of fuzzy frequency of motivation factors' third-class indexes

\begin{tabular}{|c|c|c|c|}
\hline $\mathrm{f}_{\mathrm{hp}}$ & $\mathrm{C}_{11}$ & $\mathrm{C}_{12}$ & $\mathrm{C}_{13}$ \\
\hline 1 & 0 & 0.92 & 1.92 \\
2 & 2.06 & 0.34 & 0 \\
3 & 0.34 & 1.02 & 0.76 \\
\hline $\mathrm{R}_{\mathrm{p}}$ & 2.40 & 2.28 & 2.68 \\
\hline
\end{tabular}

Table 8 . The composite scores of capacity factors' third-class indexes

\begin{tabular}{|c|c|c|c|c|}
\hline $\mathrm{B}_{\mathrm{m}}$ & $\begin{array}{c}\text { Personal capacity } \\
\left(\mathrm{C}_{21}\right)\end{array}$ & $\begin{array}{c}\text { Technical capacity } \\
\left(\mathrm{C}_{22}\right)\end{array}$ & $\begin{array}{c}\text { Equipments' capacity } \\
\left(\mathrm{C}_{23}\right)\end{array}$ & $\begin{array}{c}\text { Fiscal capacity } \\
\left(\mathrm{C}_{24}\right)\end{array}$ \\
\hline $\begin{array}{c}\text { Security Management } \\
\left(\mathrm{P}_{1}\right)\end{array}$ & 4 & 5 & 4.4 & 4.6 \\
$\begin{array}{c}\text { Sensitivity Management } \\
\left(\mathrm{P}_{2}\right)\end{array}$ & 3.2 & 4.4 & 4.8 & 4.2 \\
$\begin{array}{c}\text { Specialization Management } \\
\left(\mathrm{P}_{3}\right)\end{array}$ & 4.2 & 4.2 & 4.6 & 4.4 \\
\hline
\end{tabular}

Table 9. The degree of capacity factors' third-class indexes

\begin{tabular}{|c|c|c|c|c|}
\hline $\mathrm{U}_{\mathrm{mp}}$ & $\mathrm{C}_{21}$ & $\mathrm{C}_{22}$ & $\mathrm{C}_{23}$ & $\mathrm{C}_{24}$ \\
\hline $\mathrm{P}_{1}$ & 0.8 & 1 & 0.88 & 0.92 \\
$\mathrm{P}_{2}$ & 0.64 & 0.88 & 0.96 & 0.84 \\
$\mathrm{P}_{3}$ & 0.84 & 0.84 & 0.92 & 0.88 \\
\hline
\end{tabular}

Table 10. The statistics of fuzzy frequency of capacity factors' third-class indexes

\begin{tabular}{|c|c|c|c|c|}
\hline $\mathrm{f}_{\mathrm{hp}}$ & $\mathrm{C}_{21}$ & $\mathrm{C}_{22}$ & $\mathrm{C}_{23}$ & $\mathrm{C}_{24}$ \\
\hline 1 & 0 & 1 & 1.88 & 0 \\
2 & 0 & 0.88 & 0 & 1.8 \\
3 & 0.42 & 0.42 & 0.88 & 0.84 \\
4 & 1.86 & 0.42 & 0 & 0 \\
$\mathrm{R}_{\mathrm{p}}$ & 2.28 & 2.72 & 2.76 & 2.64 \\
\hline
\end{tabular}

Table 11. The composite scores of guarantee factors' third-class indexes

\begin{tabular}{|c|c|c|c|}
\hline $\mathrm{B}_{\mathrm{m}}$ & $\begin{array}{c}\text { Organizational } \\
\text { guarantee }\left(\mathrm{C}_{31}\right)\end{array}$ & $\begin{array}{c}\text { Supervision mechanism's } \\
\text { guarantee }\left(\mathrm{C}_{32}\right)\end{array}$ & $\begin{array}{c}\text { Institutional } \\
\text { guarantee }\left(\mathrm{C}_{33}\right)\end{array}$ \\
\hline $\begin{array}{c}\text { Security Management } \\
\left(\mathrm{P}_{1}\right)\end{array}$ & 4.2 & 4.8 & 5 \\
Sensitivity Management \\
$\begin{array}{c}\left(\mathrm{P}_{2}\right) \\
\text { Specialization } \\
\text { Management } \\
\left(\mathrm{P}_{3}\right)\end{array}$ & 4.8 & 3 & 3.4 \\
\hline
\end{tabular}


Table 12. The degree of guarantee factors' third-class indexes

\begin{tabular}{|c|c|c|c|}
\hline $\mathrm{U}_{\mathrm{mp}}$ & $\mathrm{C}_{31}$ & $\mathrm{C}_{32}$ & $\mathrm{C}_{33}$ \\
\hline $\mathrm{P}_{1}$ & 0.84 & 0.96 & 1 \\
$\mathrm{P}_{2}$ & 0.96 & 0.6 & 0.68 \\
$\mathrm{P}_{3}$ & 0.84 & 0.68 & 0.8 \\
\hline
\end{tabular}

Table 13. The statistics of fuzzy frequency of guarantee factors' third-class indexes

\begin{tabular}{|c|c|c|c|}
\hline $\mathrm{f}_{\mathrm{hp}}$ & $\mathrm{C}_{31}$ & $\mathrm{C}_{32}$ & $\mathrm{C}_{33}$ \\
\hline 1 & 1.8 & 0 & 1 \\
2 & 0 & 0.96 & 1.48 \\
3 & 0.84 & 1.28 & 0 \\
$\mathrm{R}_{\mathrm{p}}$ & 2.64 & 2.24 & 2.48 \\
\hline
\end{tabular}

Table 14. The statistics of the indexes' weights of building Chinese dangerous goods logistics " $3 \mathrm{~s}$ " management system

\begin{tabular}{|c|c|c|c|c|c|c|c|}
\hline \multirow{2}{*}{$\begin{array}{c}\text { The } \\
\text { second-class } \\
\text { indexes }\end{array}$} & \multirow[b]{2}{*}{ Weight } & \multirow{2}{*}{$\begin{array}{c}\text { The } \\
\text { third-class } \\
\text { indexes }\end{array}$} & \multicolumn{2}{|c|}{ Weight } & \multirow{2}{*}{$\begin{array}{c}\text { The } \\
\text { fourth-class } \\
\text { indexes }\end{array}$} & \multicolumn{2}{|c|}{ Weight } \\
\hline & & & $\begin{array}{c}\text { relative } \\
\text { weight }\end{array}$ & $\begin{array}{c}\text { combination } \\
\text { weights }\end{array}$ & & $\begin{array}{c}\text { relative } \\
\text { weight }\end{array}$ & $\begin{array}{c}\text { combination } \\
\text { weights }\end{array}$ \\
\hline \multirow{8}{*}{$\mathrm{B}_{1}$} & \multirow{8}{*}{0.1706} & \multirow{3}{*}{$\mathrm{C}_{11}$} & \multirow{3}{*}{0.1965} & \multirow{3}{*}{0.0335} & $\mathrm{D}_{111}$ & 0.5 & 0.0168 \\
\hline & & & & & $\mathrm{D}_{112}$ & 0.3 & 0.0101 \\
\hline & & & & & $\mathrm{D}_{113}$ & 0.2 & 0.0067 \\
\hline & & \multirow{2}{*}{$\mathrm{C}_{12}$} & \multirow{2}{*}{0.3113} & \multirow{2}{*}{0.0531} & $\mathrm{D}_{121}$ & 0.6 & 0.0319 \\
\hline & & & & & $\mathrm{D}_{122}$ & 0.4 & 0.0212 \\
\hline & & \multirow{3}{*}{$\mathrm{C}_{13}$} & \multirow{3}{*}{0.4922} & \multirow{3}{*}{0.0840} & $\mathrm{D}_{131}$ & 0.4 & 0.0336 \\
\hline & & & & & $\mathrm{D}_{132}$ & 0.25 & 0.021 \\
\hline & & & & & $\mathrm{D}_{133}$ & 0.35 & 0.0294 \\
\hline \multirow{8}{*}{$\mathrm{B}_{2}$} & \multirow{8}{*}{0.6387} & \multirow{2}{*}{$\mathrm{C}_{21}$} & \multirow{2}{*}{0.0227} & \multirow{2}{*}{0.0145} & $\mathrm{D}_{211}$ & 0.4 & 0.0058 \\
\hline & & & & & $\mathrm{D}_{212}$ & 0.6 & 0.0087 \\
\hline & & \multirow{2}{*}{$\mathrm{C}_{22}$} & \multirow{2}{*}{0.4107} & \multirow{2}{*}{0.2623} & $\mathrm{D}_{221}$ & 0.5 & 0.1312 \\
\hline & & & & & $\mathrm{D}_{222}$ & 0.5 & 0.1312 \\
\hline & & \multirow{2}{*}{$\mathrm{C}_{23}$} & \multirow{2}{*}{0.2752} & \multirow{2}{*}{0.1758} & $\mathrm{D}_{231}$ & 0.5 & 0.0879 \\
\hline & & & & & $\mathrm{D}_{232}$ & 0.5 & 0.0879 \\
\hline & & \multirow{2}{*}{$\mathrm{C}_{24}$} & \multirow{2}{*}{0.2914} & \multirow{2}{*}{0.1861} & $\mathrm{D}_{241}$ & 0.4 & 0.0744 \\
\hline & & & & & $\mathrm{D}_{242}$ & 0.6 & 0.1117 \\
\hline \multirow{6}{*}{$\mathrm{B}_{3}$} & \multirow{6}{*}{0.1907} & $C_{0}$ & 04779 & 00911 & $\mathrm{D}_{311}$ & 0.4 & 0.0364 \\
\hline & & $C_{31}$ & & & $\mathrm{D}_{312}$ & 0.6 & 0.0547 \\
\hline & & $\mathrm{C}_{3}$ & 0 1001 & 00191 & $\mathrm{D}_{321}$ & 0.6 & 0.0115 \\
\hline & & $\mathrm{C}_{32}$ & 0.1001 & 0.0191 & $\mathrm{D}_{322}$ & 0.4 & 0.0076 \\
\hline & & $\mathrm{C}_{22}$ & 04220 & 00805 & $\mathrm{D}_{331}$ & 0.3 & 0.0242 \\
\hline & & $\mathrm{C}_{33}$ & $0.4 \angle 20$ & 0.0805 & $\mathrm{D}_{332}$ & 0.7 & 0.0564 \\
\hline
\end{tabular}

